\title{
Remobilization of Dry Matter and Nitrogen in Maize as Affected by Hybrid Maturity Class
}

\author{
Silvia Pampana ${ }^{1}$, Laura Ercoli ${ }^{2}$, Alessandro Masoni ${ }^{1}$, Iduna Arduini ${ }^{1}$ \\ ${ }^{1}$ Dipartimento di Agronomia e Gestione dell'Agroecosistema, Università di Pisa \\ Via San Michele degli Scalzi 2, 56124 Pisa, Italy \\ ${ }^{2}$ Scuola Superiore Sant’Anna, Piazza Martiri della Libertà 33, 56127 Pisa, Italy
}

Received: 10 April 2009. Accepted: 31 May 2009.

\begin{abstract}
The length of the growing cycle is one of the most important traits determining hybrid adaptability to the environment. The objective of this research was to compare in a field trial the pattern of dry matter and nitrogen accumulation and remobilization of four commercial maize hybrids belonging to FAO maturity group 400, 500, 600 and 700. The duration of the periods emergence-silking and silking-physiological maturity increased with the increase of hybrid maturity class. Silking occurred 6 days later in the latest maturing hybrid than in the earliest one, and physiological maturity 21 days later. Hybrids differed for biomass production at silking and at physiological maturity. At silking, plant dry weight and leaf area increased with hybrid maturity, owing to greater leaves and stalks. The lengthening of the period emergence-silking allowed a greater accumulation of assimilates in the plant, thus increasing the source of remobilization in the following period. The increase of the length of the period silking-maturity from hybrid 400 to hybrid 700 brought to an increase of dry matter accumulation coupled to a reduction of dry matter remobilization. Increases in hybrid maturity class resulted also in an increase of post-silking $\mathrm{N}$ uptake and $\mathrm{N}$ remobilization from vegetative plant parts. Thus, the longer period silking-maturity was associated with an increased photosynthetic activity of the plant, which hampered the rate of leaf senescence and deterred the mobilization of reserve carbohydrates for grain filling. Conversely, the longer was the hybrid cycle, the greater was the quantity of both $\mathrm{N}$ uptake from soil and remobilized $\mathrm{N}$ from vegetative plant parts.
\end{abstract}

Key-words: cycle length, grain filling, hybrids, partitioning, sink-source, time to silking.

\section{Introduction}

Maize (Zea mays L.) is native to the Andean region of Central America. It is one of the most important cereals both for human and animal consumption and it is grown for grain and forage. Present world production is over 780 million tons grain and maize crops cover about 157 million ha (FAOSTAT, 2009). Maize is grown in climates ranging from temperate to tropic, profiting by the period when mean daily temperatures are above $15{ }^{\circ} \mathrm{C}$ and frost-free.

Varieties differ greatly in the adaptability to different climates. Best maize hybrids for a specific location are those that fully explore the potential growing season fitting the constraints of the local environment. Therefore, the longer the growing season, the longer the cycle length of the hybrids. Rating of hybrid maize maturity is generally performed with several systems, including FAO maturity classes (Jugenheimer, 1958) or growing degree days (GDD, Wang, 1960). All systems are based on an assumed quantitative response of maize development to temperature. Thus, maturity classes of hybrids vary for cumulative GDDs from planting to silking or to physiological maturity, so that early relative-maturity hybrids require fewer GDDs to reach silking and physiological maturity than do late relative-maturity hybrids. The former would intercept less amount of radiation than the latter ones, because of lower leaf area index and shorter growth duration, resulting in lower yield potential.

In maize as well as in other cereals, the sup- 
ply of assimilates to grain during grain filling originates from current assimilation transferred directly to kernels and from the remobilization of assimilates stored temporarily in vegetative plant parts before anthesis (Cliquet et al., 1990; Weiland and Ta, 1992; He et al., 2004). Current assimilation, as a source of carbon for grain filling, depends strongly, but not exclusively, on light interception by the photosynthetic area after anthesis. This source diminishes during grain filling due to leaf senescence, which is often fastened by stress conditions, while the carbon demand of the growing grain remains high during most of the grain-filling period. Thus, in addition to being a substrate for the maintenance of plant respiration, stem reserves are an important source of carbohydrates during the grainfilling period (Kiniry et al., 1992). The extent of stem reserve mobilization during grain filling and the proportion of these reserves in final grain mass depend on cultivar attributes, such as source:sink ratio, and are strongly influenced by prevailing environmental conditions (Pan et al., 1995).

The contribution of pre-anthesis photoassimilates to final kernel yield ranges from none to $50 \%$ in maize (Palmer et al., 1973; Fairey and Daynard, 1978; Uhart and Andrade, 1995). In contrast, the contribution of remobilized $\mathrm{N}$ to grain $\mathrm{N}$ content ranges from 30 to $70 \%$, depending on environmental conditions and/or genotype (Pollmer et al., 1979; Uhart and Andrade, 1995; Bertin and Gallais, 2000; Gallais and Coque, 2005). The metabolism of $\mathrm{C}$ and $\mathrm{N}$ are so closely linked that is seems reasonable that both $\mathrm{C}$ and $\mathrm{N}$ metabolism should be considered when attempting to identify factors that limit maize productivity. Therefore, the objective of the present research was to compare the pattern of dry matter and nitrogen accumulation and remobilization of four maize hybrids with different maturity classes, to better understand the mechanisms underlying differences among hybrids in yield formation process.

\section{Materials and methods}

The experiment was carried out in 2008 at the Department of Agronomy and Agroecosystem Management of the University of Pisa $\left(43^{\circ}\right.$ $67^{\prime} \mathrm{N}, 10^{\circ} 30^{\prime} \mathrm{E}, 5 \mathrm{~m}$ above sea level). The cli- mate is hot, humid Mediterranean with mean annual maximum and minimum daily air temperatures of 20.2 and $9.5{ }^{\circ} \mathrm{C}$ respectively, and precipitation of $971 \mathrm{~mm}$, with $368 \mathrm{~mm}$ received from April through September (511 to October), which corresponds to the maize growing season (Moonen et al., 2001).

The research was carried out in a sandy-loam soil, whose main soil physical and chemical properties were $55.5 \%$ sand $(0.05 \mathrm{~mm}<\varnothing$ $<2.00 \mathrm{~mm}), 30.7 \%$ silt $(0.002 \mathrm{~mm}<\varnothing<0.05$ $\mathrm{mm}), 13.8 \%$ clay $(\varnothing<0.002 \mathrm{~mm}), 7.2 \mathrm{pH}, 13.0$ $\mathrm{g} \mathrm{kg}^{-1}$ organic matter (Lotti method), $1.0 \mathrm{~g} \mathrm{~kg}^{-1}$ total nitrogen (Kjeldhal method), $31 \mathrm{mg} \mathrm{kg}^{-1}$ available $\mathrm{P}$ (Olsen method), $23 \mathrm{mg} \mathrm{kg}^{-1}$ available K (Dirks-Sheffer method). The preceding crop was durum wheat.

Maize hybrids KWS Karen (FAO maturity group 400), KWS Klass (FAO 500), KWS Kuadro (FAO 600) and KWS Klaxon (FAO 700) were planted on 6 May 2008 at a rate of 8.5 plants per $\mathrm{m}^{2}$ in rows spaced $50 \mathrm{~cm}$ apart. Hybrids varied in the sum of growing degree days to flowering and to physiological maturity, the latter signalled by grain black layer formation occurring approximately between 1365 and 1520 GDD from seeding. Maize hybrids were arranged in the field in a randomized block design with three replications. The plot surface was $300 \mathrm{~m}^{2}(10 \times 30 \mathrm{~m})$.

All cultural practices were similar to those routinely employed for rainfed maize in Central Italy. The experimental field was prepared with conventional tillage consisting of moalboard plow pass in autumn 2007 and disk and field cultivator on January 2008. Phosphorus and potassium were applied before ploughing at the rate of $100 \mathrm{~kg} \mathrm{ha}^{-1}$ of $\mathrm{P}_{2} \mathrm{O}_{5}$ as triple super-phosphate and $100 \mathrm{~kg} \mathrm{ha}^{-1}$ of $\mathrm{K}_{2} \mathrm{O}$ as potassium sulphate. Nitrogen was applied before seeding at the rate of $90 \mathrm{~kg} \mathrm{ha}^{-1}$ of $\mathrm{N}$, as urea, and was side dressed at V6 stage (Ritchie and Hanway, 1982), at the rate of $120 \mathrm{~kg} \mathrm{ha}^{-1}$ as ammonium nitrate. Weed control was performed at the stage of $6^{\text {th }}$ $8^{\text {th }}$ leaf by distributing commercial herbicides for annual grass and broadleaf weeds. The crop was not irrigated.

Timing of emergence (VE), silking (R1) and physiological maturity (R6) were recorded for each hybrid following the scale of Ritchie and Hanway (1982). The duration of the period emergence-silking (VE-R1) and silking-physio- 
logical maturity (R1-R6) were calculated and expressed in days and in thermal time. Thermal time was calculated as the sum of heat units measured in growing degree-days (GDD, ${ }^{\circ} \mathrm{Cd}$ ) assuming $10{ }^{\circ} \mathrm{C}$ as base temperature:

$$
\mathrm{GDD}=\left[\frac{\left(\mathrm{T}_{\text {MAX }}+\mathrm{T}_{\min }\right)}{2}\right]-\mathrm{T}_{\text {BASE }}
$$

where TMAX is the daily maximum air temperature, Tmin is the daily minimum air temperature, and TBASE is the temperature below which the process does not progress. The base temperature was incorporated into the equation, if Tmin $<$ TBASE then Tmin $=$ TBASE.

Daily weather data were obtained from a meteorological station within $100 \mathrm{~m}$ of the plot location.

At silking and grain physiological maturity plants were harvested for aboveground biomass determination. At each harvest, plants in $5-\mathrm{m}^{2}$ area were cut at ground level and separated into leaves, stalk and ears at silking, and into leaves, stalk, husks, cobs and kernels at maturity (tassels were included with the stalk in both harvests). All plant parts were oven dried at 65 ${ }^{\circ} \mathrm{C}$ to constant weight for dry weight determination. At silking plant height, leaf area per plant and LAI were determined following by McKee (1964). At maturity plant height and the number of plants and ears per unit area were also determined. Oven-dried kernels were counted and weighed to determine the number of kernels per unit area. Mean kernel weight was calculated as the ratio of kernel yield and kernel number. Plant samples were analyzed for nitrogen (microKjeldahl method) and $\mathrm{N}$ content was calculated by multiplying the $\mathrm{N}$ concentration by dry weight. Harvest index was calculated as the ratio between grain yield and total aboveground biomass at physiological maturity.

The dry matter and $\mathrm{N}$ remobilization during grain filling (DMR and NR) were calculated following Papakosta and Gagianas (1991) and Pampana et al. (2007) as:

- DMR = dry weight of the aerial plant part at silking - dry weight of leaves + stems + tassels + cobs + husks at physiological maturity;

- $\mathrm{NR}=\mathrm{N}$ content of the aerial plant part at silking - $\mathrm{N}$ content of leaves + stems + tassels + cobs + husks at physiological maturity;
For these estimates, it was assumed that all of the dry matter and $\mathrm{N}$ lost from vegetative plant parts were remobilized to the developing grain, since losses of dry matter due to plant respiration and losses of $\mathrm{N}$ due to volatilization during grain filling were not determined.

The dry matter and $\mathrm{N}$ efficiency (DMRE, NRE) were calculated as:

- DMRE $=($ DMR / dry weight of the aerial plant part at silking) $\times 100$;

- $\mathrm{NRE}=(\mathrm{NR} / \mathrm{N}$ content of the aerial plant part at silking) $\times 100$;

The contribution of dry matter and $\mathrm{N}$ remobilized to grain (CDMRG, CNRG) were calculated as:

- CDMRG = (DMR / dry weight of grain at physiological maturity) $\times 100$;

- $\mathrm{CNRG}=(\mathrm{NR} / \mathrm{N}$ content of grain at physiological maturity) $\times 100$;

Data were statistically treated by ANOVA, in order to test the main effect of hybrid. Duncan's multiple range test was used to separate the means when the ANOVA F-test indicated a significant effect of the treatment (Steel and Torrie, 1997).

\section{Results}

\subsection{Climatic conditions and cycle length}

During the maize growing season, air temperatures were close to long-term averages, while rainfall was by $50 \%$ lower than the long-term average during both the seeding-silking period and the entire growing season.

Hybrids differed for the duration of the periods emergence to silking, silking to maturity and emergence to physiological maturity, either expressed in days or in thermal time (Tab. 1). The duration of the crop cycle from emergence to physiological maturity increased with the increase of hybrid maturity class from 125 to 146 $\mathrm{d}$ or 1422.1 to $1592.6{ }^{\circ} \mathrm{Cd}$. Increments in total cycle length were related to increases in the duration of the periods emergence-silking and silking-physiological maturity. Silking occurred 6 days later in the latest maturing hybrid than in the earliest one, and physiological maturity 21 days later. Differences in cycle length recorded in this experiment were 5 days between hybrid 400 to hybrid 500, 6 days between hybrid 500 to hybrid 600 and 10 days between hybrid 600 to 
Table 1. Number of days and thermal time accumulated from emergence (VE) to silking (R1) and from silking to physiological maturity (R6) for the four maize hybrids.

\begin{tabular}{lcccccc}
\hline Hybrid & \multicolumn{2}{c}{ VE-R1 } & \multicolumn{2}{c}{$\mathrm{R} 1-\mathrm{R} 6$} & \multicolumn{2}{c}{ VE-R6 } \\
\cline { 2 - 7 } Maturity Class & $\mathrm{d}$ & ${ }^{\circ} \mathrm{Cd}$ & $\mathrm{d}$ & ${ }^{\circ} \mathrm{Cd}$ & $\mathrm{d}$ & ${ }^{\circ} \mathrm{Cd}$ \\
\hline 400 & 75 & 772.1 & 50 & 650.0 & 125 & 1422.1 \\
500 & 76 & 785.5 & 54 & 672.9 & 130 & 1458.4 \\
600 & 78 & 813.7 & 58 & 697.2 & 136 & 1511.0 \\
700 & 81 & 861.9 & 65 & 730.7 & 146 & 1592.6 \\
\hline
\end{tabular}

Table 2. Dry weight of leaves, stalk, ears and aerial biomass, plant height and LAI of the four maize hybrids at silking (R1).

\begin{tabular}{|c|c|c|c|c|c|c|}
\hline $\begin{array}{l}\text { Hybrid } \\
\text { Maturity Class }\end{array}$ & Leaves & Stalk & Ears & Aerial Biomass & Plant Height & LAI \\
\hline & & $\mathrm{D}$ & $\left(\mathrm{g} \mathrm{m}^{-2}\right)$ & & $\mathrm{cm}$ & \\
\hline 400 & $292.6 \mathrm{c}$ & $455.0 \mathrm{c}$ & $211.4 \mathrm{a}$ & $959.0 \mathrm{c}$ & $231.0 \mathrm{c}$ & $2.8 \mathrm{c}$ \\
\hline 500 & $295.8 \mathrm{c}$ & $471.7 \mathrm{c}$ & $203.6 \mathrm{ab}$ & $971.1 \mathrm{c}$ & $259.0 \mathrm{c}$ & $3.3 \mathrm{c}$ \\
\hline 600 & $386.8 \mathrm{~b}$ & $524.9 \mathrm{~b}$ & $188.2 \mathrm{bc}$ & $1099.9 \mathrm{~b}$ & $265.8 \mathrm{~b}$ & $4.2 \mathrm{~b}$ \\
\hline 700 & $450.2 \mathrm{a}$ & $608.4 \mathrm{a}$ & $173.0 \mathrm{c}$ & $1231.6 \mathrm{a}$ & $278.7 \mathrm{a}$ & $5.1 \mathrm{a}$ \\
\hline
\end{tabular}

Within columns, numbers followed by the same letter are not significantly different at $P \leq 0.05$.

hybrid 700. Thus, values were slightly lower compared to those assigned by the seed industry following FAO classification, i.e. 10 days.

\subsection{Plant growth and $N$ uptake at silking}

At silking, there were significant differences among hybrids for plant height and dry weight of all plant parts (Tab. 2). Total biomass increased with the increase of hybrid cycle length, but differences were not significant between hybrids 400 and 500 . Compared to hybrid 400, dry matter of the whole plant was by $28 \%$ higher in the hybrid 700 , owing to the higher dry weight of leaves $(54 \%)$ and stalk $(38 \%)$, and despite the lower dry weight of ears (18\%). Leaf area index also increased by $82 \%$ from hybrid 400 to 700 .

Conversely, $\mathrm{N}$ concentration in all plant parts did not vary among hybrids, averaging $0.8 \%$ in

Table 3. Nitrogen content of leaves, stalk, ears and aerial biomass of the four maize hybrids at silking (R1).

\begin{tabular}{lcccc}
\hline $\begin{array}{l}\text { Hybrid } \\
\text { Maturity Class }\end{array}$ & Leaves & Stalk & Ears & $\begin{array}{c}\text { Aerial } \\
\text { Biomass }\end{array}$ \\
\hline & \multicolumn{5}{c}{$\mathrm{g} \mathrm{m}^{-2}$} \\
400 & $3.8 \mathrm{c}$ & $3.6 \mathrm{~b}$ & $3.6 \mathrm{a}$ & $11.1 \mathrm{bc}$ \\
500 & $3.8 \mathrm{c}$ & $3.7 \mathrm{~b}$ & $3.3 \mathrm{ab}$ & $10.9 \mathrm{c}$ \\
600 & $5.0 \mathrm{~b}$ & $4.1 \mathrm{~b}$ & $3.0 \mathrm{~b}$ & $12.3 \mathrm{ab}$ \\
700 & $5.9 \mathrm{a}$ & $4.8 \mathrm{a}$ & $3.1 \mathrm{~b}$ & $14.0 \mathrm{a}$ \\
\hline
\end{tabular}

Within columns, numbers followed by the same letter are not significantly different at $P \leq 0.05$. stalk, $1.3 \%$ in leaves, and $1.7 \%$ in ears. Owing to the increase of dry weight in all plant parts, $\mathrm{N}$ content of the whole plant was by $21 \%$ higher in the hybrid 700 compared to the hybrid 400 , due to higher leaves (54\%) and stalk (34\%) N content, while that of ears was by $23 \%$ lower (Tab. 3).

Most of the dry matter and nitrogen retained in the maize plant at maturity was accumulated before silking. The proportion of accumulated dry matter in the hybrids ranged from 66 to $70 \%$ and the one of nitrogen ranged from 64 to $70 \%$ (results not shown). No clear trend of variation with the increase of maturity class was observed.

\subsection{Kernel yield and yield components}

Under the growing conditions of this experiment, the number of plants per unit area did not vary among hybrids, averaging 8.5 plants $\mathrm{m}^{-2}$. The number of ears per unit area averaged 10.7 ear $\mathrm{m}^{-2}$ in hybrids 400, 600 and 700, whereas it was lower (8.7 ear $\mathrm{m}^{-2}$ ) in hybrid 500 (Tab. 4). Kernel yield increased with the increase of maturity class, but differences among hybrids were statistically significant only between hybrid 700 and the other ones. The increase in kernel yield from hybrid 400, 500 and 600 to hybrid 700 was by $19 \%$.

Differences in kernel yield among hybrids were essentially due to the mean kernel weight, 
Table 4. Kernel yield and yield components of the four maize hybrids at physiological maturity (R6).

\begin{tabular}{lccccrr}
\hline $\begin{array}{l}\text { Hybrid } \\
\text { Maturity Class }\end{array}$ & Ear number & Kernel yield & Kernel number & Mean kernel weight & HI & NHI \\
\hline & $\mathrm{n} \mathrm{m}^{-2}$ & $\mathrm{~g} \mathrm{~m}^{-2}$ & $\mathrm{n} \mathrm{m}^{-2}$ & $\mathrm{mg}$ & $\%$ & $\%$ \\
400 & $10.0 \mathrm{a}$ & $654.4 \mathrm{~b}$ & $2528.1 \mathrm{~b}$ & $258.8 \mathrm{~b}$ & $47.5 \mathrm{a}$ & $61.4 \mathrm{a}$ \\
500 & $8.7 \mathrm{~b}$ & $711.1 \mathrm{~b}$ & $2918.2 \mathrm{a}$ & $243.7 \mathrm{~b}$ & $48.7 \mathrm{a}$ & $63.6 \mathrm{a}$ \\
600 & $11.3 \mathrm{a}$ & $727.7 \mathrm{~b}$ & $2737.4 \mathrm{ab}$ & $265.8 \mathrm{~b}$ & $44.9 \mathrm{~b}$ & $60.4 \mathrm{a}$ \\
700 & $10.7 \mathrm{a}$ & $832.2 \mathrm{a}$ & $2783.4 \mathrm{ab}$ & $299.0 \mathrm{a}$ & $44.8 \mathrm{~b}$ & $61.5 \mathrm{a}$ \\
\hline
\end{tabular}

Within columns, numbers followed by the same letter are not significantly different at $P \leq 0.05$.

which was by $17 \%$ higher in hybrid 700 compared to hybrids 400,500 and 600 . The number of kernels per unit area varied among hybrids, and was highest in hybrid $500\left(2918 \mathrm{n} \mathrm{m}^{-2}\right)$. Finally, increases in hybrid maturity class resulted in a decrease of $\mathrm{HI}$, which was by $7 \%$ lower in hybrids 600 and 700 compared to hybrids 400 and 500, while NHI did not statistically change among hybrids, averaging $61.7 \%$.

\subsection{Plant growth and $N$ uptake at physiological maturity}

At physiological maturity, total plant biomass increased with the increase of hybrid length (Tab. 5). Compared to hybrid 400, hybrid 700 had higher biomass (35\%), owing to higher leaves (45\%), stalk (47\%) and ears (28\%). No statistically significant difference for any plant part was recorded between hybrids 400 and 500, while, compared to them, values of hybrids 600 and 700 were significantly higher.

Nitrogen concentration in all plant parts did

Table 5. Dry weight and nitrogen content of leaves, stalk, ears and aerial biomass of the four maize hybrids at physiological maturity (R6).

\begin{tabular}{|c|c|c|c|c|}
\hline $\begin{array}{l}\text { Hybrid } \\
\text { Maturity Class }\end{array}$ & Leaves & Stalk & Ears & $\begin{array}{c}\text { Aerial } \\
\text { Biomass }\end{array}$ \\
\hline & \multicolumn{3}{|c|}{ Dry weight $\left(\mathrm{g} \mathrm{m}^{-2}\right)$} & \\
\hline 400 & $244.5 \mathrm{~b}$ & $304.2 \mathrm{c}$ & $830.2 \mathrm{c}$ & $1378.9 \mathrm{c}$ \\
\hline 500 & $250.6 \mathrm{~b}$ & $327.9 \mathrm{c}$ & $882.1 \mathrm{c}$ & $1460.6 \mathrm{c}$ \\
\hline 600 & $323.1 \mathrm{a}$ & $363.5 \mathrm{~b}$ & $932.6 \mathrm{~b}$ & $1619.2 \mathrm{~b}$ \\
\hline \multirow[t]{2}{*}{700} & $354.5 \mathrm{a}$ & $442.1 \mathrm{a}$ & $1059.5 \mathrm{a}$ & $1856.2 \mathrm{a}$ \\
\hline & \multicolumn{3}{|c|}{$\longrightarrow \mathrm{N}$ content $\left(\mathrm{g} \mathrm{m}^{-2}\right)$} & \\
\hline 400 & $2.4 \mathrm{~b}$ & $2.2 \mathrm{~b}$ & $11.4 \mathrm{c}$ & $16.0 \mathrm{c}$ \\
\hline 500 & $2.3 \mathrm{~b}$ & $2.3 \mathrm{~b}$ & $12.2 \mathrm{bc}$ & $16.8 \mathrm{c}$ \\
\hline 600 & $3.2 \mathrm{a}$ & $2.6 \mathrm{~b}$ & $13.5 \mathrm{~b}$ & $19.3 \mathrm{~b}$ \\
\hline 700 & $3.2 \mathrm{a}$ & $3.1 \mathrm{a}$ & $15.4 \mathrm{a}$ & $21.7 \mathrm{a}$ \\
\hline
\end{tabular}

Within columns, numbers followed by the same letter are not significantly different at $P \leq 0.05$. not vary among hybrids, averaging $0.7 \%$ in stalk, $1.0 \%$ in leaves, and $1.4 \%$ in ears. Owing to the increase of dry weight in all plant parts, $\mathrm{N}$ content of the whole plant was by $35 \%$ higher in the hybrid 700 compared to the hybrid 400 , due to higher $\mathrm{N}$ content in leaves (31\%), stalk $(45 \%)$ and ears (35\%) (Tab. 5). No statistically significant difference for $\mathrm{N}$ content in any plant part was recorded between hybrids 400 and 500, while, compared to them, values of hybrids 600 and 700 were significantly higher.

\subsection{Accumulation and remobilization of dry matter}

Accumulated dry matter during grain filling in consequence of current photosynthesis (DMA) increased with the increase of hybrid cycle length (Tab. 6). Thus, the amount of DMA was by $24 \%$ higher in hybrid 700 compared to hybrids 500 and 600 and by $20 \%$ higher in hybrids 500 and 600 compared to hybrid 400 . No statistically significant difference was recorded between DMA of hybrids 500 and 600. Conversely, remobilized dry matter (DMR) decreased with the increase of hybrid cycle length. The decrease was by $12 \%$ from hybrid 400 to hybrid 700. Post-anthesis accumulation of dry matter was higher than remobilization of dry matter in

Table 6. Post-anthesis dry matter accumulation (DMA), dry matter remobilized into grain (DMR), dry matter remobilization efficiency (DMRE) and contribution of remobilization to grain yield (CDMR) of the four maize hybrids.

\begin{tabular}{|c|c|c|c|c|}
\hline $\begin{array}{l}\text { Hybrid } \\
\text { Maturity Class }\end{array}$ & DMA & DMR & DMRE & CDMR \\
\hline & \multicolumn{2}{|c|}{$-\mathrm{g} \mathrm{m}^{-2}$} & \multicolumn{2}{|c|}{$\%$} \\
\hline 400 & $419.9 \mathrm{c}$ & $234.5 \mathrm{a}$ & $24.5 \mathrm{a}$ & $35.8 \mathrm{a}$ \\
\hline 500 & $489.5 \mathrm{c}$ & $221.6 \mathrm{ab}$ & $22.8 \mathrm{ab}$ & $31.2 \mathrm{~b}$ \\
\hline 600 & $519.3 \mathrm{~b}$ & $208.4 \mathrm{~b}$ & $18.9 \mathrm{~b}$ & $28.6 \mathrm{~b}$ \\
\hline 700 & $624.6 \mathrm{a}$ & $207.6 \mathrm{~b}$ & $16.9 \mathrm{c}$ & $24.9 \mathrm{c}$ \\
\hline
\end{tabular}

Within columns, numbers followed by the same letter are not significantly different at $P \leq 0.05$. 
Table 7. Post-anthesis nitrogen accumulation (NA), nitrogen remobilized into grain (NR), nitrogen remobilization efficiency (NRE) and contribution of remobilized nitrogen to nitrogen content of grain (CNR).

\begin{tabular}{|c|c|c|c|c|}
\hline $\begin{array}{l}\text { Hybrid } \\
\text { Maturity Class }\end{array}$ & NA & NR & NRE & CNR \\
\hline & \multicolumn{2}{|c|}{$\mathrm{g} \mathrm{m}^{-2}$} & \multicolumn{2}{|c|}{$\%$} \\
\hline 400 & $4.9 \mathrm{~d}$ & $4.9 \mathrm{~b}$ & $44.4 \mathrm{a}$ & $50.3 \mathrm{a}$ \\
\hline 500 & $5.8 \mathrm{c}$ & $4.8 \mathrm{~b}$ & $44.2 \mathrm{a}$ & $45.4 \mathrm{~b}$ \\
\hline 600 & $7.0 \mathrm{c}$ & $4.7 \mathrm{~b}$ & $38.0 \mathrm{~b}$ & $40.2 \mathrm{c}$ \\
\hline 700 & $7.7 \mathrm{a}$ & $5.6 \mathrm{a}$ & $40.2 \mathrm{~b}$ & $42.1 \mathrm{c}$ \\
\hline
\end{tabular}

Within columns, numbers followed by the same letter are not significantly different at $P \leq 0.05$.

all hybrids, and the ratio accumulated/remobilized dry matter increased from 1.8 in hybrid 400 to 3 in hybrid 700 . The increase in hybrid maturity class resulted in a decreased efficiency of dry matter remobilization during grain filling, which was by $31 \%$ lower in hybrid 700 compared to hybrid 400. As a consequence of the variations in DMA and DMR among hybrids, the contribution of remobilized dry matter to kernel yield decreased with the increase of cycle length (from $36 \%$ of hybrid 400 to $25 \%$ of hybrid 700 ).

\subsection{Accumulation and remobilization of nitrogen}

The increase in hybrid maturity class resulted in an increase of the nitrogen accumulated in the plant during grain filling (NA), which was by $58 \%$ higher in hybrid 700 compared to hybrid 400 (Tab. 7). Remobilized N did not vary among hybrids 400,500 and 600 and was by $16 \%$ higher in hybrid 700. The remobilization of nitrogen equalled post-anthesis accumulation in hybrid 400 , while in the others $\mathrm{N}$-accumulation was higher than $\mathrm{N}$-remobilization and the ratio NA/NR increased with the increase of hybrid cycle length. Genotypic variations were also observed for nitrogen remobilization efficiency (NRE), with hybrids 400 and 500 exhibiting $12 \%$ higher values than hybrids 600 and 700 . As a result, the proportions of remobilized $\mathrm{N}$ in the grain (CNR) differed among the four hybrids, decreasing with the increase of hybrid cycle length (from $50 \%$ of hybrid 400 to $42 \%$ of hybrid 700 ).

\section{Discussion and conclusions}

In maize crop, kernel yield depends on the relationship between the number of kernels per unit area, referred as kernel sink capacity, and the mean kernel weight. Kernel sink capacity is highly dependent on growing conditions during the early stages of grain filling. Mean kernel weight is affected by the availability of assimilates to fill this sink, i.e. the source capacity (Simmons and Jones, 1985; Jones et al., 1996), and, therefore, it reflects both the conditions before silking, affecting the source of remobilization, and the conditions during grain filling, influencing the rate of accumulation and remobilization of assimilates into kernels (Borrás et al., 2004).

In our research, kernel yield increased with the increase of hybrid maturity class by $27 \%$ from hybrid 400 to hybrid 700 , as a result of a $10 \%$ increase of the number of kernels per unit area and of a $17 \%$ increase of the mean kernel weight. Thus, differences in kernel weight among hybrids depended more on variations of sink capacity than on variations on source capacity. The increase in kernel number was accompanied by a greater increase in leaf area index, leading to an increase in current assimilation. Following Maddoni et al. (1998), total aboveground biomass gain per kernel during the post-silking period was taken as a variable reflecting assimilate availability for grain filling. Values (of plant weight gain per kernel) increased with the increase of hybrid maturity class from $166.1 \mathrm{mg} \mathrm{kernel}{ }^{-1}$ in hybrid 400 to $224.4 \mathrm{mg} \mathrm{kernel}^{-1}$ in hybrid 700 . The ratio between mean kernel weight and plant weight gain per kernel was in all hybrids greater than 1 , indicating that the exceeding kernel demand was satisfied by remobilization, and this condition was particularly evident in shorter cycle hybrids. The kernel demand for nitrogen was also higher than the post-silking $\mathrm{N}$ uptake per kernel and the imbalance between them decreased with the increase of cycle length.

Hybrids differed for the duration of both the periods emergence to silking and silking to physiological maturity, and for biomass production at silking and at physiological maturity. At silking, plant dry weight and leaf area increased with hybrid maturity, owing to greater leaves and stalks. The lengthening of the period emergence-silking allowed a greater accumulation of assimilates in the plant, thus increasing the source of remobilization in the following period. The length of the period silking-maturity increased from hybrid 400 to hybrid 700 and this 
increase brought to an increase of dry matter accumulation coupled to a reduction of dry matter remobilization. Increases in hybrid maturity class resulted also in an increase of post-silking $\mathrm{N}$ uptake and $\mathrm{N}$ remobilization from vegetative plant parts. Thus, the longer period silking-maturity was associated with an increased photosynthetic activity of the plant, which hampered the rate of leaf senescence and deterred the mobilization of reserve carbohydrates for grain filling (Rajcan and Tollenaar, 1999; Borrell et al., 2001). Conversely, the longer was the hybrid cycle, the greater was the quantity of both $\mathrm{N}$ uptake from soil and remobilized $\mathrm{N}$ from vegetative plant parts. We can hypothesize that the increased amount of remobilized $\mathrm{N}$ does not derive from degradation of proteins from senescing leaves but from $\mathrm{N}$ temporarily stored in stalks and not associated to the activity of the photosynthetic apparatus. Similarly, Subedi and Ma (2005) found that when $N$ supply was unrestricted, maize took up $\mathrm{N}$ continuously beyond 3 weeks after silking and that the $\mathrm{N}$ taken up at this later stage was accumulated mainly in the stalk. The important role of $\mathrm{N}$ availability is confirmed by Paponov and Engels (2005), who found that remobilization of $\mathrm{N}$ from vegetative plant parts was covered mainly by depletion of stem $\mathrm{N}$ at high $\mathrm{N}$ supply and by depletion of leaf $\mathrm{N}$ at low $\mathrm{N}$ supply.

In all hybrids, most of the dry matter and nitrogen retained in the maize plant was accumulated before silking, but significant accumulation of dry matter and $\mathrm{N}$ from current photosynthesis into kernels occurred also during grain filling. Dry matter and nitrogen accumulation during grain filling were greater than remobilization, so that the contribution of remobilization to grain yield did not reach $36 \%$, and for $\mathrm{N}$ remobilization it accounted for $42-50 \%$ of grain $\mathrm{N}$ content.

The $\mathrm{C}$ to $\mathrm{N}$ ratio $(\mathrm{w} / \mathrm{w})$ of the accumulated and remobilized materials can be estimated assuming that the carbon concentration in DM is $50 \%$. Thus, in this experiment, the $\mathrm{C} / \mathrm{N}$ ratio of the accumulated material during grain filling decreased with the increase of hybrid maturity class, from 24 in hybrid 400 to 19 in hybrid 700. This indicates that the relative contribution of carbohydrates to remobilization decreases with the increase of hybrid cycle length and conversely that the one of proteins increases. The different $\mathrm{C} / \mathrm{N}$ ratio in mobilized biomass may be related to differences in the sources of pre-anthesis mobilization, either water-soluble carbohydrates, soluble proteins, starch, organic acids, lipids or structural carbohydrates (Gebbing and Schnyder, 1999). The relative contribution of the number of compounds involved in remobilization to kernels and their effects on kernels quality is still not clear and needs further elucidation (Borrás et al., 2002).

\section{References}

Bertin P., Gallais A. 2000. Genetic variation for nitrogen use efficiency in a set of recombinant maize inbred lines. I Agrophysiological results. Maydica, 45:53-66.

Borrás L., Curá J.A., Otegui M.E. 2002. Maize kernel composition and post-flowering source-sink ratio. Crop Sci., 42:781-790.

Borrás L., Slafer G., Otegui M. 2004. Seed dry weight response to source-sink manipulations in wheat, maize and soybean: a quantitative reappraisal. Field Crops Res., 86:131-146.

Borrell A., Hammer G., Van Oosterom E. 2001. Stay green: A consequence of the balance between supply and demand for nitrogen during grain filling? Ann. Appl. Biol., 138:91-95.

Cliquet J.B., Deleens E., Mariotti A. 1990. C and N mobilization from stalk and leaves during kernel filling by ${ }^{13} \mathrm{C}$ and ${ }^{15} \mathrm{~N}$ tracing in Zea mays L. Plant Physiol., 94:1547-1553.

Fairey N.A., Daynard T.B. 1978. Quantitative distribution of assimilates in component organs of maize during reproductive growth. Can. J. Plant Sci., 58:709-717.

FAOSTAT, 2009. Production of crops [web page] http:// faostat.fao.org/site/567/default.aspx\#ancor [accessed 18 March 2009].

Gallais A., Coque M. 2005. Genetic variation and selection for nitrogen use efficiency in maize: a synthesis. Maydica, 50:531-547.

Gebbing T., Schnyder H. 1999. Pre-anthesis reserve utilization for protein and carbohydrate synthesis in grains of wheat. Plant Physiol., 121:871-878.

He P., Zhou W., Jin J.Y. 2004. Carbon and nitrogen metabolism related to grain formation in two different senescent types of maize. J. Plant Nutr., 27:295-311.

Jones R.J., Schreiber B.M.N., Roessler J.A. 1996. Kernel sink capacity in maize: genotypic and maternal regulation. Crop Sci., 36:301-306.

Jugenheimer R.W. 1958. Hybrids maize breeding and seed production. FAO Agric. Dev. Pop. No 62:99-103.

Kiniry J.R., Tischler C.R., Rosenthal W.D., Gerik T.J. 1992. Nonstructural carbohydrate utilization by sorghum and maize shaded during grain growth. Crop Sci., 32:131-137. 
Maddoni G.A., Otegui M.E., Bonhomme R. 1998. Grain yield components in maize: II. Postsilking growth and kernel weight. Field Crops Res., 56:257-264.

McKee G.W. 1964. A coefficient for computing leaf area in hybrid corn. Agron. J., 56:240-241.

Moonen C., Masoni A., Ercoli L., Mariotti M., Bonari E. 2001. Long-term changes in rainfall and temperature in Pisa, Italy. Agr. Med., 130:11-22.

Palmer A.F.E., Heichel G.E., Musgrave R.B. 1973. Patterns of translocation, respiratory loss and distribution of ${ }^{14} \mathrm{C}$ in maize labeled after flowering. Crop Sci., 13:371-376.

Pampana S., Mariotti M., Ercoli L., Masoni A. 2007. Remobilization of dry matter, nitrogen and phosphorus in durum wheat as affected by genotype and environment. Ital. J. Agron., 3:303-314.

Pan W.L., Camberato J.J., Moll R.H., Lamprath E.J., Jackson W.A. 1995. Altering source-sink relationships in prolific maize hybrids: consequences for nitrogen uptake and remobilisation. Crop Sci., 35:836-845.

Papakosta D.K., Gagianas A.A. 1991. Nitrogen and dry matter accumulation, remobilization and losses for Mediterranean wheat during grain filling. Agron. J., 83:864-870.

Paponov I.A., Engels C. 2005. Effect of nitrogen supply on carbon and nitrogen partitioning after flowering in maize. J. Plant Nutr. Soil Sci., 168:447-453.

Pollmer W.G., Eberhard D., Klein D., Dhillon B.S. 1979.
Genetic control of nitrogen uptake and translocation in maize. Crop Sci., 19:82-86.

Rajcan I., Tollenaar M. 1999. Source: sink ratio and leaf senescence in maize: I. Dry matter accumulation and partitioning during grain filling. Field Crops Res., 60:245-253.

Ritchie S.W., Hanway J.J. 1982. How a corn plant develops. Spec. Rept. No. 48 Iowa State University of Science and Technology. Cooperative Extension Service, Ames IA.

Simmons S.R., Jones R.J. 1985. Contributions of presilking assimilate to grain yield in maize. Crop Sci., 25:1004-1006.

Steel R.D.G., Torrie J.H. 1997. Principles and procedures of statistics. McGraw-Hill, New York.

Subedi K.D., Ma B.L. 2005. Nitrogen uptake and partitioning in stay-green and leafy maize hybrids. Crop Sci., 45:740-747.

Uhart S.A., Andrade F.H. 1995. Nitrogen and carbon accumulation and remobilization during grain filling in maize under different source/sink ratios. Crop Sci., 35:183-190.

Wang J.Y. 1960. A critique of the heat unit approach to plant response studies. Ecology, 4:785-790.

Weiland R.T., Ta T.C. 1992. Allocation and retranslocation of ${ }^{15} \mathrm{~N}$ by maize (Zea mays L.) hybrids under field conditions of low and high $\mathrm{N}$ fertility. Aust. J. Plant Physiol., 19:77-88. 